Conference

Circuit

\title{
Library instruction for changing times
}

\section{By Gary B. Thompson}

\section{The 25th Workshop on Instruction in Library Use}

$\mathbf{T}$ he five Canadian librarians in attendance at the inaugural LOEX (Library Orientation Exchange) Conference in 1971 were so impressed by the proceedings that they clecided to establish a similar seminar for librarians from their two provinces. In 1972 the first Workshop on Instruction in Library Use (WILU) was held at the University of Western Ontario and it has been held every year since then, either in Ontario or Quebec province. The 25th anniversary Workshop on Instruction in Library Use held at Wilfrid Laurier University in Waterloo, Canada, May 15-17, attracted close to 100 participants, 20 percent of whom were from the United States.

\section{The forces challenging academic libraries today}

The keynote speaker was Roma Harris, viceprovost and registrar and professor in the School of Library Science at the University of Western Ontario, who identified three forces challenging academic libraries today: greater demands for services, expanding electronic information resources, and smaller budgets and smaller staffs, especially professional librarians. Some critics of library instruction think that academic libraries should deliver information and stop forcing students to learn how to use libraries, while others believe that students must become more self-reliant and find information with minimal help.

Citing studies of user behavior done by herself, Gloria Leckie and Heidi Julien, Carol Kulthau and Cerise Oberman, Harris pointed out that students are bewildered by the variety of electronic resources, frequently encounter problems searching these databases without assistance, are anxious about how to pick and narrow down a research topic, and are overwhelmed by the mountains of citations. She stated that librarians must teach the entire research process, including selecting the indexes, choosing the topic, narrowing the focus, developing search strategies, selecting relevant citations, and evaluating the intellectual content of the sources located. Librarians must teach students how to take full advantage of electronic resources by encouraging the discovery process and developing discerning minds, to separate the chaff from the wheat.

Harris posed this dilemma: "In the examples of the misclirected patrons, the ONLY reason their problems were identified was because a librarian noticed them struggling, approached them, and worked with them to find out what they were trying to accomplish. How many people will now fall through the cracks, walking away empty-handed or, at best, poorly informed by the technological front-ends to our self-service arrangements."

\section{High-touch help}

Today there is much talk about the virtual library and the virtual university, but people do not live and work in virtual reality. Harris pointed out that high tech requires "high-touch" help: "educating users to navigate and understand the role of information, and to use critical thinking in the evaluation of material they retrieve, is, by definition, a labor-intensive process, whether it be carried out by librarians or faculty members. There is not much question that if we are to have an educated, thoughtful population we must find ways to ensure that people do not drown in ignorance as a result of swimming in a sea of data." She concluded 
by saying that librarians are the best gatekeepers to ensure that the widest range of information remains a public good accessible to all segments of the population. As the costs of education rise, students will demand that academic libraries provide assistance and instruction on using the electronic resources. "There is no question about whether the need exists to instruct users and to teach them to use critical thought in negotiating the complex world of information. The question is whether we can succeed in claiming the resources necessary to provide this education."

\section{The human factor in teaching and learning}

The other conference highlight was a breakout session entitled "Reflective Teaching and Thinking" given by Donald Morgenson, professor emeritus and winner of many teaching awards at Wilfrid Laurier University. Like Harris, Morgenson addressed the human factor in teaching and learning in this highly technological educational environment. He implored librarians to help reverse the decline in reflective thought and to transform students into critical and conceptual thinkers actively involved in the learning process. With the transfer of more and more data into computer storage, there is a danger that knowledge may become compressed into small "info-nuggets" and that longer and more fully developed discourses on these subjects may be lost.

Morgenson pointed out that every research tool, whether it be a pencil or a computer, has its limitations as well as its benefits. If we are not careful, reliance upon electronic and Internet resources may restrict researchers to a limited number of resources, in brief and bland versions, filtered by others based upon commercial gain, efficiency, and ease of use. Librarians must teach students to assess and interpret what they read, to discern the good from the bad, and to take the time to apply critical thinking to the research process. Computers may make research seem too easy and too fast, resulting in quick and dirty research.

Morgenson agreed with those librarians who convened recently at the New York Public Library to discuss the future of libraries. They concluded that the future library must be a haven for people wanting access to electronic information and a human gathering place for people interested in research, reading, reflection, discussion, and dialogue. This place will need computers, but it will also need librarians to educate and guide patrons so that they are well-informed citizens with a solid understanding of the facts to make informed judgments about issues facing the country and the world.

\section{Innovations in instruction}

In another breakout session, Shabiran Rahman (University of Waterloo) presented the results of her extensive survey of undergraduate and graduate students and faculty, which probed such questions as how faculty encourage students to learn about the library, how students acquire library skills, how useful students think library instruction is, and which materials and which services students think are the most important to them.

Many presenters at this conference demonstrated the versatility of Web browser software for making library instruction more attractive, more creative, and more rewarding for teachers and students. Web browsers also may be

\section{Today there is much talk about the virtual library and the virtual university, but people do not live end work in virtual reality.}

more cost-effective since the materials are always available to students at a moment's notice and can be easily adapted to new uses.

The poster sessions offered several innovative ideas: a "certificate of participation in library workshops" to let faculty know that students received the needed instruction (Laurentian University), "Elements of a Good Library Research Paper Assignment" for use by teaching faculty (Wabash College), "English 102e-Technical Writing on the World Wide Web" including a virtual classroom (University of Waterloo), and an interactive CD-ROM for teaching library and information-gathering skills (Wascana Institute in Regina).

\section{Talk: Formal and informal}

Much of the formal and informal talk at the conference centered around the growth of electronic resources and information technology, the cuts in library budget and staff resources, and their combined impact on the outlook for library instruction everywhere. 